\title{
Effects of Different Potassium Stress on Leaf Photosynthesis and Chlorophyll Fluorescence in Maize (Zea Mays L.) at Seedling Stage
}

\author{
Xinhua Zhao, Qi Du, Yue Zhao, Huajie Wang, Yanjie Li, Xiaoguang Wang, Haiqiu Yu \\ College of Agronomy, Shenyang Agricultural University, Shenyang, China \\ Email: haiqiuyu@163.com
}

Received 16 December 2015; accepted 25 January 2016; published 28 January 2016

Copyright (C 2016 by authors and Scientific Research Publishing Inc.

This work is licensed under the Creative Commons Attribution International License (CC BY).

http://creativecommons.org/licenses/by/4.0/

c) (i) Open Access

\begin{abstract}
Leaf early senescence caused by nutrition deficiency is one of the major limitation reasons in the world crop production. Potassium (K) is one of important nutrient elements in crop growth, which modifies dozens of enzyme activations and controls stomatal movement of photosynthesis. The yield and quality of maize (Zea Mays L.) have been limited due to $\mathrm{K}$ deficiency in plough layer soil. However, the mechanism of $\mathrm{K}$ deficiency tolerance is not fully understood in maize. In this study, two inbred lines, 099 (tolerance to potassium deficiency) and 835 (sensitive to potassium deficiency) were carried out to investigate the variations of chlorophyll content, photosynthetic and chlorophyll fluorescence parameters related with senescence under different $\mathrm{K}^{+}$concentrations in maize at seedling stage. The results showed that the Chlorophyll $a, b$ and $(a+b)$ of 835 were significantly decreased under different $K$ deficiency treatments, whereas those of 099 were remained normal. In addition, 099 showed a lower stomatal restriction and higher electronic transition capacity under different $K$ deficiency treatments. The variations of $F_{0}, F_{v} / F_{m}, \Phi_{P S I}, q P$ and NPQ in 835 were largely higher than those in 099 . These results indicated that the inbred line 099 tolerance to $\mathrm{K}$ deficiency could keep chlorophyll content to maintain photosynthesis and to alleviate the injury of PSII under $\mathrm{K}$ deficiency condition. This study should contribute to explaining the physiological mechanism tolerance nutrition deficiency and improving breeding program in maize.
\end{abstract}

\section{Keywords}

Potassium Deficiency, Maize, Leaf Senescence, Photosynthetic Parameters, Chlorophyll Fluorescence 


\section{Introduction}

Maize (Zea mays L.) is one of the most important cereal crops world-wide as well as an important source of feed, fibre, and biofuel. Potassium (K) as one of the essential nutrients for crop plays an important role in crop growth and development, metabolism and yield formation process [1] [2]. Because of long-term agricultural production of existing cultivated land, there is about $60 \%$ of massive arable land potassium deficiency, which inhibit crop yield and quality improvement [3] [4]. Meanwhile, the price of $\mathrm{K}$ fertilizers has been rapidly increased with rising energy prices, which lead to increased input in crop production. In Northeast China, an insufficient supply of $\mathrm{K}$ in soils often limits maize production to meet the demand for food from the growing population [4]-[6]. Therefore, it has been proposed that screening maize genotypes efficient use of potassium and clarifying the physiological mechanism of tolerance to potassium deficiency can reduce the use of expensive $\mathrm{K}$ fertilizers in agriculture [7]-[9].

The leaf senescence shortens the duration of the photosynthesis after heading, and reduces the photosynthetic production accumulation [10]-[12]. Potassium deficiency in plants usually induces brown scorching and curling of leaf tips as well as chlorosis (yellowing) between leaf veins, which accelerate leaf senescence. Leaf photosynthesis consists of the several physiological processes, including light harvesting, photosystem II (PSII) photochemistry and $\mathrm{CO}_{2}$ assimilation [13]. Potassium deficiency disrupted the leaf photosynthetic organ, and led to declining in net photosynthetic rate, stomatal conductance, RuBPcase activity and obviously decreasing grain production in rice [14]. The study in soybean showed that a relatively high content of Chl $a, b$ and $(a+b)$, especially the increase of Chl $a$ content in K efficiency variety, resulted in a high ability of photosynthesis. The effective transfer of photosynthetic electron was another factor in maintaining the ability, while the significant changes of those parameters led to decrease of photosynthesis ability for K inefficiency variety [15].

Chlorophyll fluorescence measurements have increasingly been used as a non-invasive tool in leaf ecophysiological studies. This method has been used extensively to investigate the response of plants to environmental stress, including the effects of low potassium on the photosynthetic apparatus of crops both in a controlled environment and in the field [16] [17]. In particular, it can assess PSII electron $\left(\mathrm{e}^{-}\right)$transport efficiency simultaneously, a number of photosynthesis parameters underlying physiological responses to environmental variables can be estimated [18] [19]. Increasing Nitrogen (N) nutrition could improve the PSII potential activity, increased maximum quantum yield in wheat, whereas decreased non-photochemical quenching and increased the net photosynthetic rate $\left(\mathrm{P}_{\mathrm{n}}\right)$. However, nitrogen deficiency could decrease the quantum yield of PSII electron transport and the maximal efficiency of PSII (Fv/Fm) photochemistry rate. Nevertheless, little has been reported about the relations of leaf senescence, photosynthesis and chlorophyll fluorescence.

In present study, we designed an experiment to explore the different expression of photosynthesis and chlorophyll fluorescence using two typical maize inbred lines under four potassium treatment levels. Meanwhile, we want to verify the mechanization of resistance to senescence and the physiological mechanism of higher photosynthesis productivity in maize inbred lines tolerant to K deficiency.

\section{Material and Methods}

\subsection{Plant Materials and Experimental Design}

Two maize inbred line screened in our previous study, 099 (tolerance to $\mathrm{K}^{+}$deficiency) and 835 (sensitive to $\mathrm{K}^{+}$ deficiency), were carried out to compare the different in hydroponic method at the experiment station of Shenyang Agricultural University. After disinfecting in $7 \% \mathrm{NaClO}_{3}$ solution, the selected full and uniform seed were germinated at $25^{\circ} \mathrm{C}$ in waterish sand on June 28, 2014. When two leaves were fully expanded, 12 seedlings per inbred line were washed with distilled water and carefully transplanted into an experimental lightproof plastic pot in the rainproof greenhouse under natural environment. The pot was $50 \mathrm{~cm} \times 35 \mathrm{~cm} \times 15 \mathrm{~cm}$ and contained $20 \mathrm{~L}$ nutrient solution. The row spacing was $7.5 \mathrm{~cm}$ and the plant spacing was $6.5 \mathrm{~cm}$.

\subsection{Treatment}

The nutrient solution was modified with $1 / 2$ Hoagland's nutrient solution and Arnon microelement, containing $2000 \mu \mathrm{mol} \mathrm{Ca}\left(\mathrm{NO}_{3}\right)_{2} \cdot 4 \mathrm{H}_{2} \mathrm{O}, 1000 \mu \mathrm{mol} \mathrm{MgSO} \cdot 7 \mathrm{H}_{2} \mathrm{O}, 500 \mu \mathrm{mol} \mathrm{NH}_{4} \mathrm{H}_{2} \mathrm{PO}_{4}, 100 \mu \mathrm{mol} \mathrm{FeSO} \cdot 7 \mathrm{H}_{2} \mathrm{O}, 100 \mu \mathrm{mol}$ EDTA, $23 \mu \mathrm{mol} \cdot \mathrm{H}_{3} \mathrm{BO}_{3}, 6.3 \mu \mathrm{mol} \mathrm{MnSO}_{4} \cdot \mathrm{H}_{2} \mathrm{O}, 0.16 \mu \mathrm{mol} \mathrm{CuSO} \cdot \cdot 5 \mathrm{H}_{2} \mathrm{O}, 0.383 \mu \mathrm{mol} \mathrm{ZnSO} \cdot 7 \cdot 7 \mathrm{H}_{2} \mathrm{O}, 0.8092 \mu \mathrm{mol}$ $\left(\mathrm{NH}_{4}\right)_{6} \mathrm{Mo}_{7} \mathrm{O}_{24}$. Four levels of $\mathrm{K}^{+}$treatment were adjusted at $0 \mathrm{mmol} \cdot \mathrm{L}^{-1}, 0.625 \mathrm{mmol} \cdot \mathrm{L}^{-1}, 1.25 \mathrm{mmol} \cdot \mathrm{L}^{-1}$ and 2.5 $\mathrm{mmol} \cdot \mathrm{L}^{-1}$ (control) using $\mathrm{KNO}_{3}$. A randomized complete block design was employed using a 2-way factorial 
arrangement of treatments with three replications for each treatment. The oxygen was pumped to nutrient solution for 45 min every 15 min by automatic control electric pump. The $\mathrm{pH}$ value of solution was adjusted to 6.0 everyday by $0.1 \mathrm{~mol} / \mathrm{L} \mathrm{NaOH}$ or $\mathrm{HCl}$ and the solutions were replaced every week. After 9 days of treatment, the new expanded leaves of three representative seedlings per inbred line were selected to measure chlorophyll content, gas exchange parameters and chlorophyll fluorescence parameters in each treatment. All measurements were carried out between 9:30 and 11:30.

\subsection{Measurement}

\subsubsection{Chlorophyll (Chl) Content}

Chl $a, b$ and Chl $(a+b)$ were measured according to the methods of Li et al. (2011) [20]. Every Sample containing $100 \mathrm{mg}$ of fresh leaf was extracted by $10 \mathrm{~mL}$ acetone and ethylalcohol $(1: 1, \mathrm{v} / \mathrm{v})$ at dark place for $24 \mathrm{~h}$ until the sample changed to white [21]. Pigment concentrations were measured by using an UV-spectrophotometer (Shimadzu UV-1601, Japan). Then the absorbance was recorded at $645 \mathrm{~nm}$ and $663 \mathrm{~nm}$.

\subsubsection{Gas Exchange Parameters}

Gas exchange was measured with a CIRAS-2 portable open-flow gas exchange system attached to internal LED with red/white light source (PP systems, Hansatech, UK). The chamber was set at airflow rate of $100 \mathrm{~mL} \cdot \mathrm{min}^{-1}$, $\mathrm{CO}_{2}$ concentration of $390 \pm 5 \mu \mathrm{mol} \cdot \mathrm{mol}^{-1}$, photosynthetic phtoton flux density of $1200 \mu \mathrm{mol} \cdot \mathrm{m}^{-2} \cdot \mathrm{s}^{-1}$. The net photosynthetic rate $\left(\mathrm{P}_{\mathrm{n}}\right)$, transpiration rate $\left(\mathrm{T}_{\mathrm{r}}\right)$, stomatal conductance $\left(\mathrm{G}_{\mathrm{s}}\right)$ and intercellular $\mathrm{CO}_{2}$ concentration $\left(\mathrm{C}_{\mathrm{i}}\right)$ were measured on the upper fully expanded leaf.

\subsubsection{Chlorophyll Fluorescence Parameters}

Chlorophyll fluorescence parameters were measured with FMS-2 (Hansatech, UK) at the same leaves after keeping in the dark for 20 min, including minimal fluorescence $\left(\mathrm{F}_{0}\right)$, the maximum quantum efficiency of PSII photochemistry $\left(\mathrm{F}_{\mathrm{v}} / \mathrm{F}_{\mathrm{m}}\right)$, actual photochemical efficiency of PSII $\left(\Phi_{\mathrm{PSII}}\right)$, photochemical quenching $(\mathrm{qP})$, nonphotochemical quenching (NPQ).

\subsection{Statistical Analysis}

The mean values of three replications were calculated for each trait and used in data analysis using Excel 2013. Data among the different treatments and inbred lines were analyzed using TWO-way ANOVA $(\mathrm{p} \leq 0.05)$ method. The analysis was carried out using SPSS22.0 software for windows 8.

\section{Results}

\subsection{Effects of $\mathrm{K}^{+}$Deficiency on Chl Content}

The variations of Chl $a$, Chl $b$ and Chl $a+b$ content were shown in Table 1 . With the $\mathrm{K}^{+}$concentration decreasing, the value of Chl $a$, Chl $b$ and Chl $(a+b)$ in 835 and 099 were largely reduced. The Chl $a$, Chl $b$ and Chl ( $a$ $+b)$ of 835 were significant decreased comparing with CK at $0.625 \mathrm{mmol} / \mathrm{L}$. The Chl $a$ and $(a+b)$ of 835 were significantly decreased from $2.5 \mathrm{mmol} / \mathrm{L}$ to $0 \mathrm{mmol} / \mathrm{L}$, while those of 099 were only slightly decreased. Under the same $\mathrm{K}^{+}$concentration, the $\mathrm{Chl} a$, Chl $b$ and Chl $(a+b)$ of 099 were significantly higher than those of 835 .

\subsection{Effects of $\mathbf{K}^{+}$Deficiency on Photosynthetic Characteristics}

\subsubsection{Net Photosynthetic Rate $\left(\mathrm{P}_{\mathrm{n}}\right)$}

With the $\mathrm{K}^{+}$concentration decreasing, the two inbred lines showed different declining (Figure 1). Comparing with the control, the $\mathrm{P}_{\mathrm{n}}$ of 835 were significantly decreased at $0 \mathrm{mmol} / \mathrm{L}, 0.625 \mathrm{mmol} / \mathrm{L}$ and $1.25 \mathrm{mmol} / \mathrm{L}$ by $70.73 \%, 29.87 \%, 19.68 \%$, respectively. However, the $\mathrm{P}_{\mathrm{n}}$ of 099 were little decreased by $61.07 \%, 12.60 \%$ and 4.53\% under K deficiency. Although there was no difference between 099 and 835 in control, the $\mathrm{P}_{\mathrm{n}}$ of 099 were significantly higher than 835 at $0.625 \mathrm{mmol} / \mathrm{L}$ and $1.25 \mathrm{mmol} / \mathrm{L}$, by $25.88 \%$ and $20.07 \%$.

\subsubsection{Intercellular $\mathrm{CO}_{2}$ Concentration $\left(\mathrm{C}_{\mathrm{i}}\right)$}

The $\mathrm{C}_{\mathrm{i}}$ of two inbred lines was decreased with the $\mathrm{K}^{+}$concentration increasing (Figure 2). There was no differ- 
Table 1. Effects of potassium deficiency on chlorophyll content between two maize inbred lines.

\begin{tabular}{|c|c|c|c|c|}
\hline Inbred line & $\mathrm{K}^{+}$concentration $(\mathrm{mmol} / \mathrm{L})$ & Chl $a$ (mg/g) & Chl $b(\mathrm{mg} / \mathrm{g})$ & Chl $(a+b)(\mathrm{mg} / \mathrm{g})$ \\
\hline \multirow{4}{*}{099} & 0.000 & $1.129 \pm 0.15 b c$ & $0.302 \pm 0.03 \mathrm{ab}$ & $1.431 \pm 0.223 \mathrm{bc}$ \\
\hline & 0.625 & $1.77 \pm 0.093 \mathrm{a}$ & $0.475 \pm 0.027 \mathrm{a}$ & $2.244 \pm 0.132 \mathrm{a}$ \\
\hline & 1.250 & $1.82 \pm 0.129 a$ & $0.495 \pm 0.029 a b$ & $2.315 \pm 0.151 \mathrm{ab}$ \\
\hline & 2.500 & $1.853 \pm 0.142 \mathrm{a}$ & $0.523 \pm 0.032 \mathrm{a}$ & $2.376 \pm 0.207 a$ \\
\hline \multirow{4}{*}{835} & 0.000 & $0.641 \pm 0.123 \mathrm{e}$ & $0.225 \pm 0.022 c$ & $0.866 \pm 0.11 \mathrm{e}$ \\
\hline & 0.625 & $1.033 \pm 0.092 \mathrm{~d}$ & $0.298 \pm 0.022 b c$ & $1.331 \pm 0.093 \mathrm{de}$ \\
\hline & 1.250 & $1.09 \pm 0.131 d$ & $0.325 \pm 0.03 b c$ & $1.415 \pm 0.129 \mathrm{de}$ \\
\hline & 2.500 & $1.217 \pm 0.127 \mathrm{c}$ & $0.366 \pm 0.027 \mathrm{bc}$ & $1.583 \pm 0.142 \mathrm{~cd}$ \\
\hline
\end{tabular}

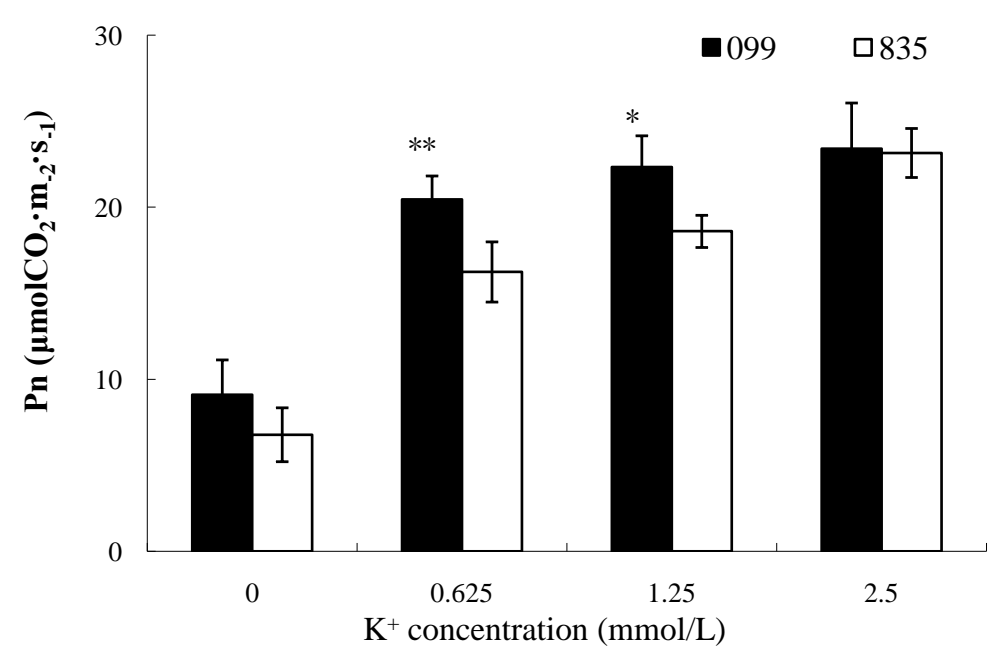

Figure 1. Effect of different $\mathrm{K}^{+}$concentration on $\mathrm{P}_{\mathrm{n}}$ in two inbred lines.

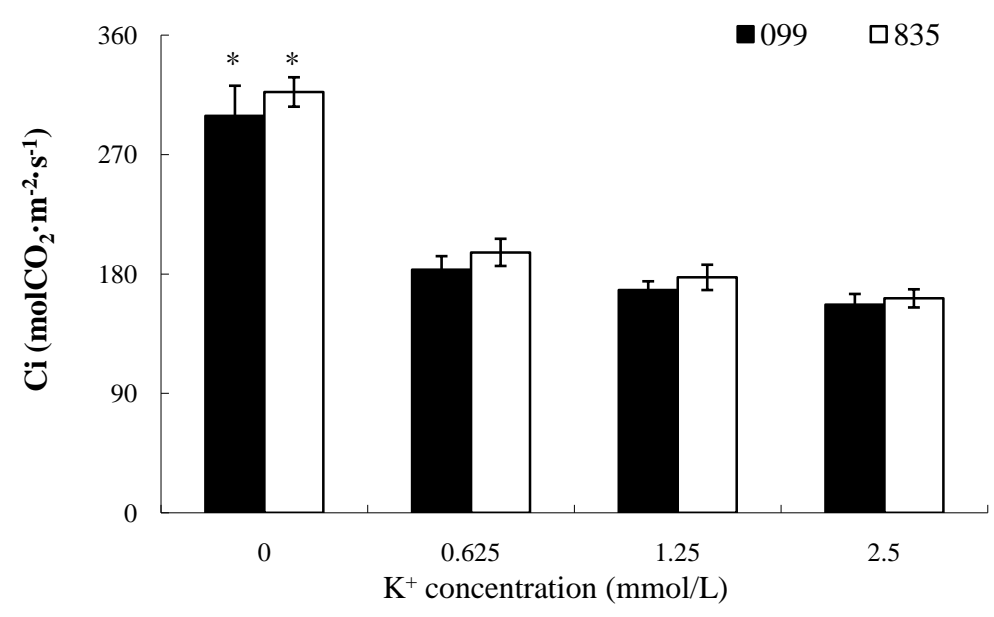

Figure 2. Effect of different $\mathrm{K}^{+}$concentration on $\mathrm{C}_{\mathrm{i}}$ in two inbred lines.

ence in the control, whereas those of 835 were slightly higher than those of 099 at $0 \mathrm{mmol} / \mathrm{L}, 0.625 \mathrm{mmol} / \mathrm{L}$ and $1.25 \mathrm{mmol} / \mathrm{L}$, by $6.03 \%, 7.09 \%$ and $5.60 \%$. The $\mathrm{C}_{\mathrm{i}}$ of 099 and 835 were significant increasing by $90.77 \%$ and $96.26 \%$ at $0 \mathrm{mmol} / \mathrm{L}$, respectively. 


\subsubsection{Stomatal Conductance $\left(\mathrm{G}_{\mathrm{s}}\right)$}

With the $\mathrm{K}^{+}$concentration decreasing, the $\mathrm{G}_{\mathrm{s}}$ of 835 and 099 were significantly declined (Figure 3). Comparing with control, the $\mathrm{G}_{\mathrm{s}}$ of 099 and 835 were decreased by 10.49\%, 20.65\%, 41.30\% and $17.74 \%, 33.87 \%, 60.97 \%$ from $2.5 \mathrm{mmol} / \mathrm{L}$ to $0 \mathrm{mmol} / \mathrm{L}$. Under $\mathrm{K}$ deficiency, those of 099 were significantly higher than those of 835 at 0 $\mathrm{mmol} / \mathrm{L}$ and $0.625 \mathrm{mmol} / \mathrm{L}$, whereas there was no significantly under other treatments.

\subsubsection{Transpiration Rate $\left(\mathrm{T}_{\mathrm{r}}\right)$}

The $\mathrm{T}_{\mathrm{r}}$ of 099 were decreased from $4.65 \mathrm{mmol} \mathrm{CO} \mathrm{m}^{-2} \cdot \mathrm{s}^{-1}$ to $3.04 \mathrm{mmol} \mathrm{CO}_{2} \mathrm{~m}^{-2} \cdot \mathrm{s}^{-1}$ with the $\mathrm{K}^{+}$concentration decreasing (Figure 4), while the $\mathrm{T}_{\mathrm{r}}$ of 835 were little declined from $4.35 \mathrm{mmol} \mathrm{CO}_{2} \mathrm{~m}^{-2} \cdot \mathrm{s}^{-1}$ to $2.66 \mathrm{mmol} \mathrm{CO}_{2}$ $\mathrm{m}^{-2} \cdot \mathrm{s}^{-1}$. It was showed that the $\mathrm{T}_{\mathrm{r}}$ of 835 were larger decreased than those of 099 under $\mathrm{K}$ deficiency. There was not significantly different between two inbred lines at $1.25 \mathrm{mmol} / \mathrm{L}$ and $2.5 \mathrm{mmol} / \mathrm{L}$, whereas the $\mathrm{T}_{\mathrm{r}}$ of 099 was significantly higher than that of 835 at $0.625 \mathrm{mmol} / \mathrm{L}$.

\subsection{Effects of K Deficiency on Chlorophyll Fluorescence Parameters}

\subsubsection{Minimal Fluorescence $\left(\mathrm{F}_{0}\right)$}

With the decreasing of $\mathrm{K}^{+}$concentration, the $\mathrm{F}_{0}$ of two inbred lines were largely increased (Figure 5). The $\mathrm{F}_{0}$ of 099 was decreased by $21.58 \%$ at $0 \mathrm{mmol} / \mathrm{L}$ comparing with control, whereas that of 835 was significantly decreased $45.06 \%$. Under $\mathrm{K}$ deficiency, the $\mathrm{F}_{0}$ of 835 were largely increased from $2.5 \mathrm{mmol} / \mathrm{L}$ to $0 \mathrm{mmol} / \mathrm{L}$ by

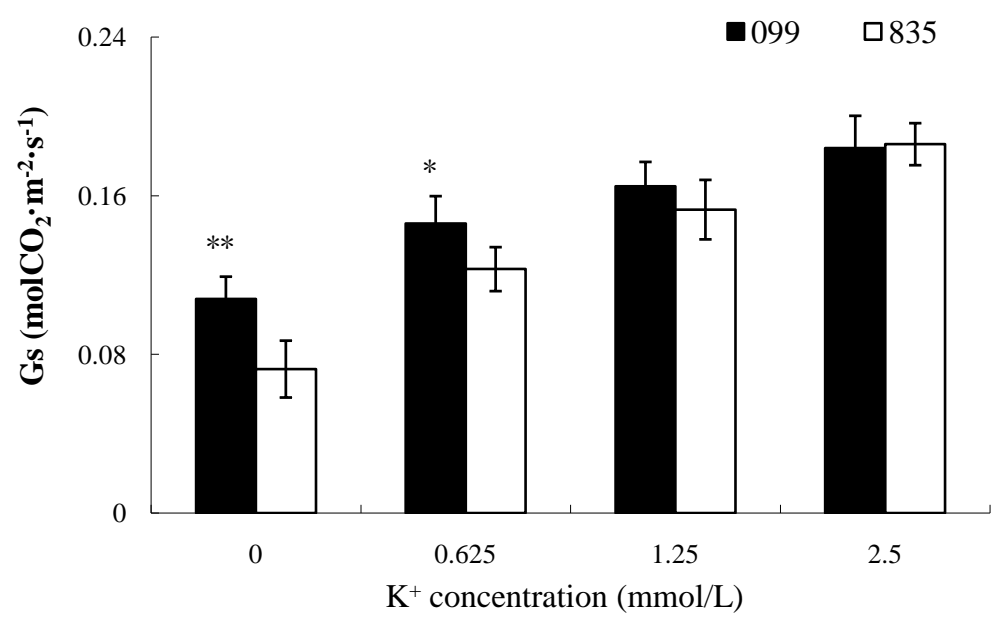

Figure 3. Effect of different $\mathrm{K}^{+}$concentration on $\mathrm{G}_{\mathrm{s}}$ in two inbred lines.

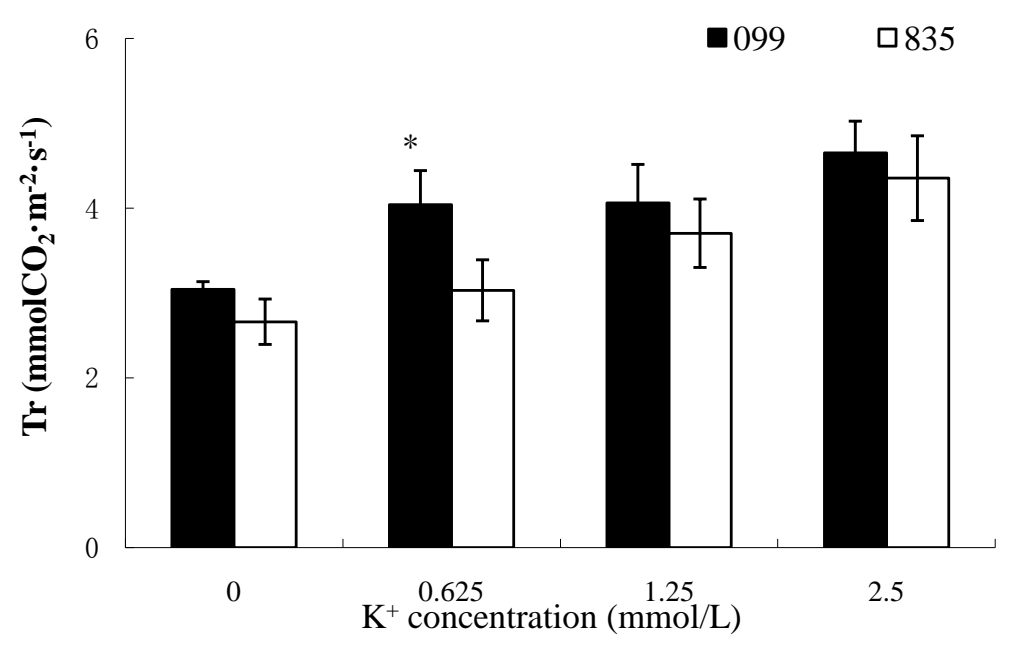

Figure 4. Effect of different $\mathrm{K}^{+}$concentration on $\mathrm{T}_{\mathrm{r}}$ in two inbred lines. 
$13.92 \%, 10.89 \%$ and $6.91 \%$, whereas that of 099 was slightly increased.

\subsubsection{Maximum Quantum Efficiency of PSII Photochemistry $\left(\mathrm{F}_{\mathrm{v}} / \mathrm{F}_{\mathrm{m}}\right)$}

The $\mathrm{F}_{\mathrm{v}} / \mathrm{F}_{\mathrm{m}}$ of two inbred lines was decreased from $2.5 \mathrm{mmol} / \mathrm{L}$ to $0 \mathrm{mmol} / \mathrm{L}$ (Figure 6). The $\mathrm{F}_{\mathrm{v}} / \mathrm{F}_{\mathrm{m}}$ of 099 was significantly higher than those of 835 at $0 \mathrm{mmol} / \mathrm{L}$ and $0.625 \mathrm{mmol} / \mathrm{L}$, by $25.47 \%, 10.61 \%$ respectively. The $\mathrm{F}_{\mathrm{v}} / \mathrm{F}_{\mathrm{m}}$ of 835 at $0.625 \mathrm{mmol} / \mathrm{L}$ was significantly lower than control, whereas there was no different for 099 .

\subsubsection{Actual Photochemical Efficiency of PSII ( $\left.\Phi_{\text {PSII }}\right)$}

The $\Phi_{\text {PSII }}$ of two inbred lines were decreased with the decreasing of the $\mathrm{K}^{+}$concentration (Figure 7). The $\Phi_{\text {PSII }}$ of 099 were significantly higher than that of 835 from $0 \mathrm{mmol} / \mathrm{L}$ to $2.5 \mathrm{mmol} / \mathrm{L}$ by $88.66 \%, 92.35 \%, 42.80 \%$ and $30.33 \%$, respectively. Comparing with the control, the $\Phi_{\text {PSII }}$ of 099 was not significantly lower except at 0 $\mathrm{mmol} / \mathrm{L}$, whereas that of 835 were largely decreased at $0 \mathrm{mmol} / \mathrm{L}$ and $0.625 \mathrm{mmol} / \mathrm{L}$.

\subsubsection{Photochemical Quenching (qP)}

The qP is commonly used to reflect the degree of opening of the reaction center. With the decreasing of $\mathrm{K}^{+}$concentration, the qP of 835 were largely decreased from $2.5 \mathrm{mmol} / \mathrm{L}$ to0mmol/L (Figure 8 ). The $\mathrm{qP}$ of 099 were

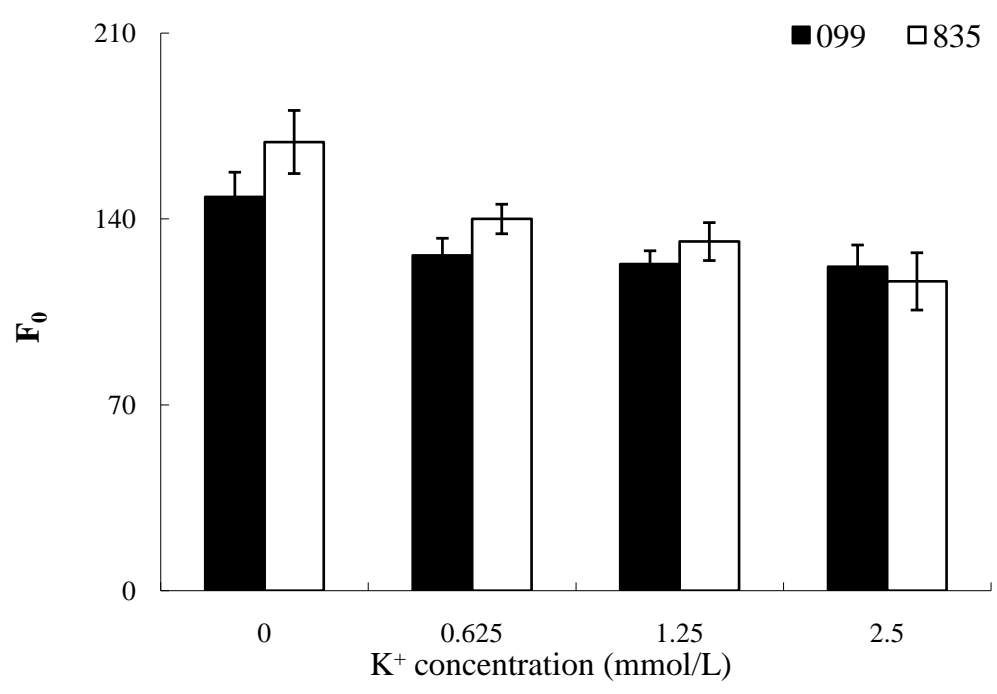

Figure 5. Effect of different $\mathrm{K}^{+}$concentration on $\mathrm{F}_{0}$ in two inbred lines.

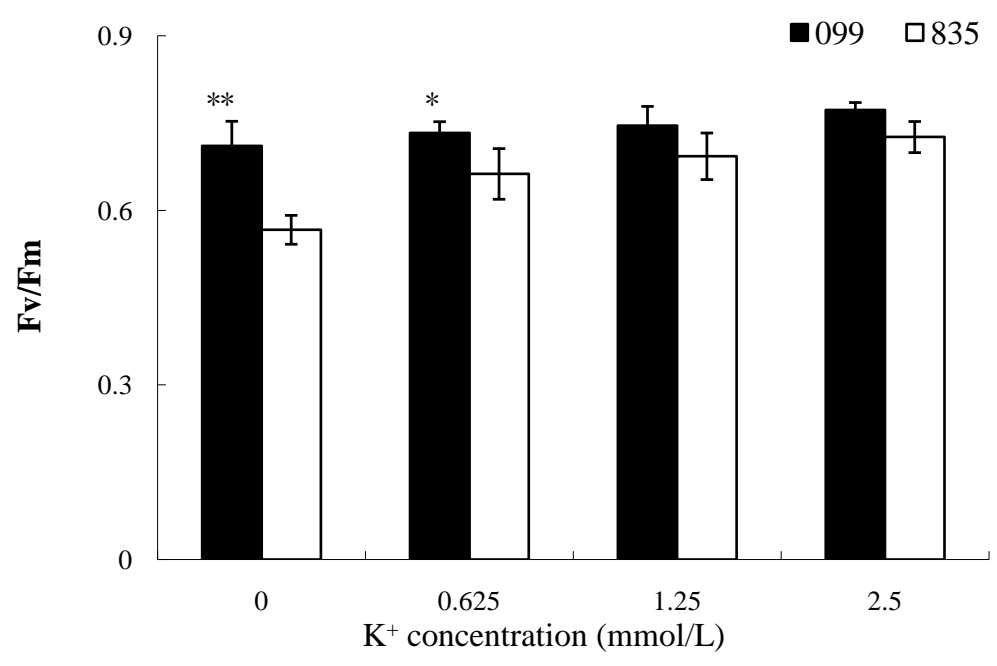

Figure 6. Effect of different $\mathrm{K}^{+}$concentration on $\mathrm{F}_{\mathrm{v}} / \mathrm{F}_{\mathrm{m}}$ in two inbred lines. 


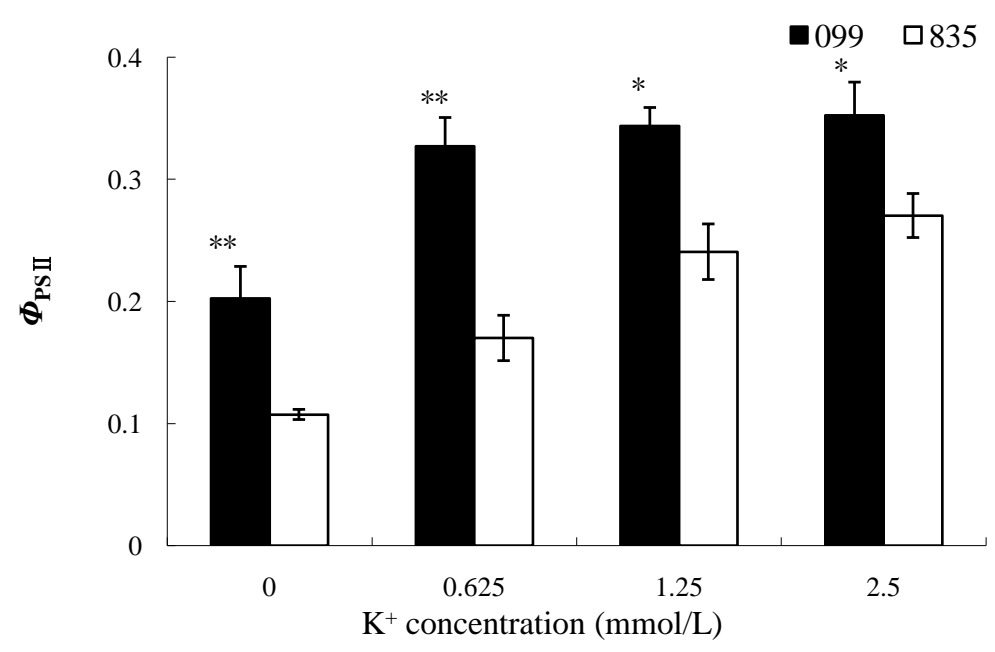

Figure 7. Effect of different $\mathrm{K}^{+}$concentration on $\Phi_{\mathrm{PSII}}$ in two inbred lines.

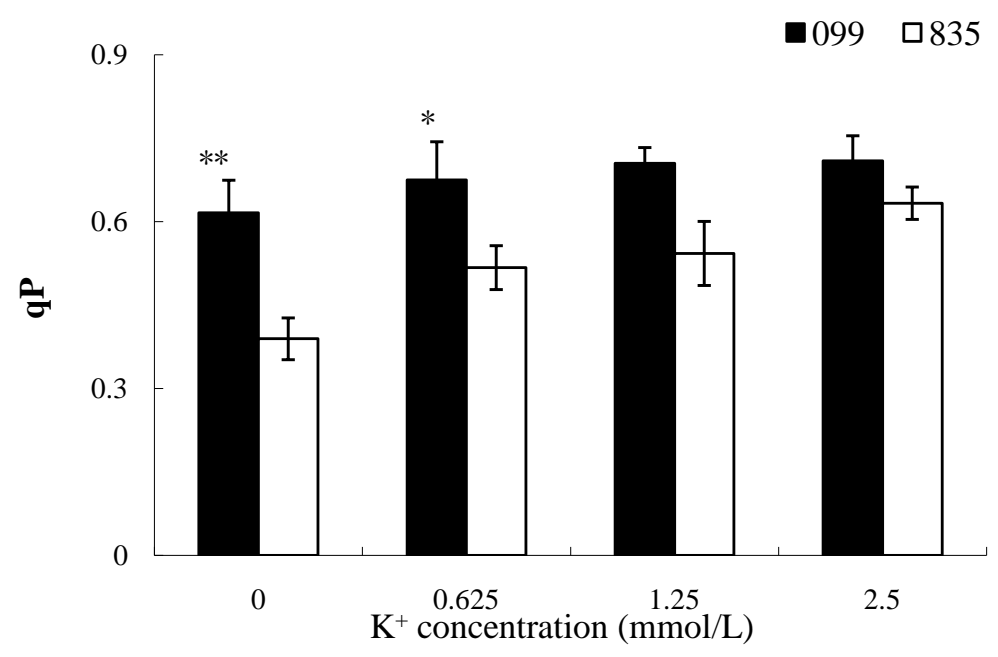

Figure 8. Effect of different $\mathrm{K}^{+}$concentration on qP in two inbred lines.

significantly higher than those of 835 under K deficiency. Comparing with the control, the qP of 835 were significantly decreased by $38.49 \%$ and $18.29 \%$ at $0 \mathrm{mmol} / \mathrm{L}$ and $0.625 \mathrm{mmol} / \mathrm{L}$.

\subsubsection{Non-Photochemical Quenching (NPQ)}

The NPQ reflects the change of the ability of plant heat dissipation. The NPQ of two inbred lines increased gradually from $2.50 \mathrm{mmol} / \mathrm{L}$ to $0 \mathrm{mmol} / \mathrm{L}$ (Figure 9). The NPQ of 099 were largely higher than those of 835 at different $\mathrm{K}^{+}$concentration. At $0 \mathrm{mmol} / \mathrm{L} \mathrm{K}^{+}$concentration, the NPQ of 099 was significantly increased by $21.79 \%$, while that of 835 was slightly increased.

\section{Discussion}

Leaf senescence comprises a series of biochemical and physiological events [11] [22]. The ability to maintain green leaf area is one of the important physiological traits that have an implication on yield potential related to increasing assimilate availability [23]-[25]. However, several reports has described that many abiotic stresses, including nutrient deficiency, could not result in uniform symptoms, but rather on visible patches or color variation on leaf surfaces and margin [26]. Chlorophyll degradation during senescence is an early and, for membrane polypeptides, essential event. If chlorophyll breakdown in senescence is prevented, the process of senescence could be delayed. In the present study, the Chl $a, b$ and $\mathrm{Chl}(a+b)$ of 099 were not varied significantly at 


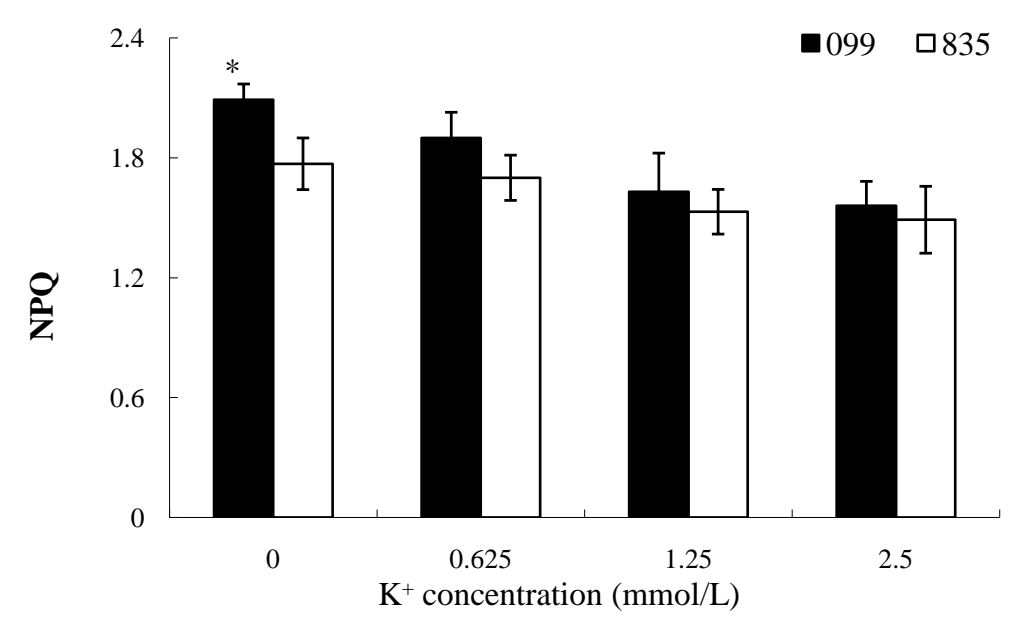

Figure 9. Effect of different $\mathrm{K}^{+}$concentration on NPQ in two inbred lines.

$0.625 \mathrm{mmol} / \mathrm{L}$ and $1.250 \mathrm{mmol} / \mathrm{L}$, whereas those of 099 were significantly decreased at $0 \mathrm{mmol} / \mathrm{L}$. To the contrary, those of 835 were significantly declined under $\mathrm{K}$ deficiency comparing with control. Under the same $\mathrm{K}^{+}$ concentration, the the Chl $a, b$ and Chl $(a+b)$ of 099 were significantly higher than those of 835. Those results showed that the progress of leaf senescence was more slowly in 099 than in 835 under potassium deficiency stress.

Leaf photosynthesis consists of the several physiological processes, that is, light harvesting, PSII photochemistry, and $\mathrm{CO}_{2}$ assimilation [13]. The photosynthetic functions, including PSII photochemistry, were inhibited as a result of nutrients deficiency, which directly influence the photosynthetic apparatus through biosynthesis and functioning of key photosynthetic components [27]. For example, nitrogen, sulphur and iron deficiencies could directly influence the synthesis of protein complexes in photosynthetic reactions [28] [29]. Potassium plays an important role in stomatal function by maintaining turgor pressure [30]. Under potassium deficiency stress, the leaf net photosynthetic rate, stomatal conductance, photosynthetic phosphorylation activity and electron transfer energy were decreased in rice, cotton [31] [32]. In addition, Xu et al. (2010) assumed that photosynthetic $\mathrm{CO}_{2}$ conductance limit was divided into stomatal limitation and non-stomatal limitation, which the later is largely concerned with the transmission of $\mathrm{CO}_{2}$ [33]. In the present study, the $\mathrm{P}_{\mathrm{n}}, \mathrm{C}_{\mathrm{i}}, \mathrm{G}_{\mathrm{s}}$ and $\mathrm{T}_{\mathrm{r}}$ of 099 and 835 were no significant different at $2.5 \mathrm{mmol} / \mathrm{L}$. However, the $\mathrm{P}_{n}, \mathrm{G}_{\mathrm{s}}$ and $\mathrm{T}_{\mathrm{r}}$ of 835 were significantly decreased under $\mathrm{K}$ deficiency and the $\mathrm{Ci}$ was largely increased. On the contrary, those of 099 were slightly affected under $\mathrm{K}$ deficiency. These results demonstrated that the photosynthetic system of 099 tolerance to K deficiency could remain natural function under K deficiency.

In recent years, the measurement of chlorophyll fluorescence parameters has provided a rapid non-destructive method to obtain precise information about the state of photosynthetic apparatus and especially of PSII [34] [35]. Osório et al. (2014) reported that Chlorophyll fluorescence parameters $\left(\mathrm{F}_{\mathrm{v}} / \mathrm{F}_{\mathrm{m}}, \Phi_{\mathrm{PSII}}, \mathrm{NPQ}\right.$, qP) showed a significant variation with greater values in midrib areas in strawberry on 42th day after Fe deficiency [26]. In addition, Kalaji et al. (2014) demonstrated that the electron donation by oxygen evolving complex (OEC) was significantly decreased in Mg and Ca deficient plants [27]. However, Sulphur deficiency resulted in a limitation of electron transport beyond PSI, probably on account of decreasing in the PSI content or activity of PSI electron acceptors. To the contrary, they considered that the PSII activity was affected much more than PSI in Ca deficiency plants. To further explore the internal causes of decline in photosynthesis due to potassium deficiency, we conducted chlorophyll fluorescence parameters measured at different $\mathrm{K}^{+}$concentrations. It can be seen from the results that in the condition of potassium deficiency, $\Phi_{\text {PSII }}$ of 099 and 835 were declined, which was conrresponding with the increasing of $\mathrm{F}_{0}$. These results showed that the change and photoinhibition in 099 were lesser than in 835 under $\mathrm{K}$ potassium. The variable fluorescence and maximum fluorescence reflect the electron transport system smoothly or not in PSII. In the present study, the electron transferred in 099 was more smoothly than that in 835 under different K deficiency. These results can explain that PSII of 099 suffered damage to a lesser extent, maintaining relative high photochemical efficiency and strong photosynthetic capacity. 


\section{Conclusion}

In the present study, two typical maize inbred lines were carried out to measure the different of photosynthesis and chlorophyll fluorescence at different $\mathrm{K}^{+}$concentration. The results indicated that the $P_{n}, G_{s}, T_{r}, F_{v} / F_{m}, q P$, $\Phi_{\text {PSII }}$ and ETR of 099, tolerance to K deficiency, were significantly higher than those of 835 under $\mathrm{K}^{+}$deficiency treatments, whereas the $\mathrm{C}_{\mathrm{i}}$ and $\mathrm{F}_{0}$ of 099 were lower. These results indicated that the 099 could prolong leaf senescence and have higher photosynthesis to maintain plant growth under $\mathrm{K}^{+}$deficiency condition.

\section{Acknowledgements}

The work was financially supported by the Tianzhu Mountian Scholars Support Plan of Shenyang Agricultural University, the National Natural Science Foundation of China (31301259), the National Key Technology R\&D Program (2013BAD07B03).

\section{References}

[1] Cao, M.J., Yu, H.Q. and Yan, H.K. (2007) Difference in Tolerance to Potassium Deficiency between Two Maize Inbred Lines. Plant Production Science, 10, 42-46. http://dx.doi.org/10.1626/pps.10.42

[2] Marschner, H., and Marschner, P. (2011) Marschner's Mineral Nutrition of Higher Plants. Elsevier, London, UK.

[3] Pettigrew, W.T. (2008) Potassium Influences on Yield and Quality Production for Maize, Wheat, Soybean and Cotton. Physiologia Plantarum, 133, 670-681. http://dx.doi.org/10.1111/j.1399-3054.2008.01073.x

[4] Jin, J.Y. (2012) Changes in the Efficiency of Fertiliser Use in China. Journal of the Science of Food and Agriculture, 92, 1006-1009. http://dx.doi.org/10.1002/jsfa.4700

[5] Römheld, V. and Kirkby, E.A. (2010) Research on Potassium in Agriculture: Needs and Prospects. Plant Soil, 335, 155-180. http://dx.doi.org/10.1007/s11104-010-0520-1

[6] Coskun, D., Britto, D.T. and Kronzucker, H.J. (2014) The Physiology of Channel-Mediated K ${ }^{+}$Acquisition in Roots of Higher Plants. Physiologia Plantarum, 151, 305-312. http://dx.doi.org/10.1111/ppl.12174

[7] Rengel, Z. and Damon, P.M. (2008) Crops and Genotypes Differ in Efficiency of Potassium Uptake and Use. Physiologia Plantarum, 133, 624-636. http://dx.doi.org/10.1111/j.1399-3054.2008.01079.x

[8] Fageria, N.K. (2009) The Use of Nutrients in Crop Plants. CRC Press, Boca Raton, FL.

[9] Guo, H.R., Yu, H.Q. and Jiang, C.J. (2009) Difference of Root Traits and Potassium Efficiency in Different Tolerant Maize at Seedling Stage under Potassium Deficiency. Crops, 129, 62-65. (In Chinese)

[10] Gentinetta, E., Ceppi, D., Perico, G., Motto, M. and Salamini, F.A. (1986) Major Gene for Delayed Senescence in Maize: Pattern of Photosynthates Accumulation and Inheritance. Plant Breeding, 97, 193-203. http://dx.doi.org/10.1111/j.1439-0523.1986.tb01053.x

[11] Lim, P.O., Kim, H.J. and Nam, H.G. (2007) Leaf Senescence. Annual Review of Plant Biology, 58, 115-136. http://dx.doi.org/10.1146/annurev.arplant.57.032905.105316

[12] Stefan, H. (2009) Stay-Green Regulates Chlorophyll and Chlorophyll-Binding Protein Degradation during Senescence. Trends in Plant Science, 14, 155-162. http://dx.doi.org/10.1016/j.tplants.2009.01.002

[13] Etsushi, K., Ken, J. I., Satoshi, U., Keiichi, O., Cevayir, C. and Shizuo, A. (2011) Silica Crystals and Aluminum Salts Regulate the Production of Prostaglandin in Macrophages via NALP3 Inflammasome-Independent Mechanisms. Immunity, 34, 514-526. http://dx.doi.org/10.1016/j.immuni.2011.03.019

[14] Liu, J.C., Li, J.S., Mi, G.H., Chen, F.J. and Zhang, F.S. (2009) QTL Mapping of Seedling Growth Traits and Grain Yield under Two Nitrogen Conditions in Maize. Scientia Agricultura Sinica, 42, 3413-3420. (In Chinese)

[15] Jiang, C.C., Chen, F., Gao, X.Z., Lu, J.W., Wan, K.Y., Nian, F.Z. and Wang, Y.H. (2008) Study on the Nutrition Characteristics of Different K Use Efficiency Cotton Genotypes to K Deficiency Stress. Agricultural Science in China, 7, 740-745. http://dx.doi.org/10.1016/S1671-2927(08)60109-1

[16] Haldimann, P., Fracheboud, Y. and Stamp, P. (1996) Photosynthetic Performance and Resistance to Photoinhibition of Zea mays L. Leaves Grown at Suboptimal Temperature. Plant, Cell and Environment, 19, 85-92. http://dx.doi.org/10.1111/j.1365-3040.1996.tb00229.x

[17] Wang, X.G., Zhao, X.H., Jiang, C.J., Li, C.H., Cong, S., Wu, D., Chen, Y.Q., Yu, H.Q. and Wang, C.Y. (2015) Effects of Potassium Deficiency on Photosynthesis and Photoprotection Mechanisms in Soybean (Glycine max (L.) Merr.). Journal of Integrative Agriculture, 14, 856-863. http://dx.doi.org/10.1016/S2095-3119(14)60848-0

[18] Laisk, A. and Loreto, F. (1996) Determining Photosynthetic Parameters from Leaf $\mathrm{CO}_{2}$ Exchange and Chlorophyll 
Fluorescence: Rubisco Specificity Factor, Dark Respiration in the Light, Excitation Distribution between Photosystems, Alternative Electron Transport and Mesophyll Diffusion Resistance. Plant Physiology, 110, 903-912.

[19] Peterson, R.B., Oja, V. and Laisk, A. (2001) Chlorophyll Fluorescence at 680 and 730 nm and Leaf Photosynthesis. Photosynthesis Research, 70, 185-196. http://dx.doi.org/10.1023/A:1017952500015

[20] Li, X.T., Cao, P., Wang, X.G., Cao, M.J. and Yu, H.Q. (2011) C Comparison of Gas Exchange and Chlorophyll Fluorescence of Low-Potassium-Tolerant and -Sensitive Soybean [Glycine max (L.) Merr.] Cultivars under Low-Potassium Condition. Photosynthetica, 49, 633-636. http://dx.doi.org/10.1007/s11099-011-0073-4

[21] Huang, C.J., Wei, G., Jie, Y.C. Wang, L.C., Zhou, H.F., Ran, C.Y., Huang, Z.C., Jia, H.J. and Anjum S.A. (2014) Effects of Concentrations of Sodium Chloride on Photosynthesis, Antioxidative Enzymes, Growth and Fiber Yield of Hybrid Ramie. Plant Physiology and Biochemistry, 76, 86-93. http://dx.doi.org/10.1016/j.plaphy.2013.12.021

[22] Thomas, H. and Smart, C.M. (1993) Crops That Stay Green. Annals of Applied Biology, 123, 193-219. http://dx.doi.org/10.1111/j.1744-7348.1993.tb04086.x

[23] Thomas, H. and Howarth, C.J. (2000) Five Ways to Stay Green. Journal of Experimental Botany, 51, 329-337. http://dx.doi.org/10.1093/jexbot/51.suppl_1.329

[24] Zhang, Z., Li, G., Gao, H., Zhang, L., Yang, C., Liu, P. and Meng, Q. (2012) Characterization of Photosynthetic Performance during Senescence in Stay-Green and Quick-Leaf-Senescence Zea mays L. Inbred Lines. PLoS ONE, 7, e42936. http://dx.doi.org/10.1371/journal.pone.0042936

[25] Gregersen, P.L., Culetic, A., Boschian, L. and Krupinska, K. (2013) Plant Senescence and Crop Productivity. Plant Molecular Biology, 82, 603-622. http://dx.doi.org/10.1007/s11103-013-0013-8

[26] Osório, J., Osório, M.L., Correia, P.J., de Varennes, A. and Pestana, M. (2014) Chlorophyll Fluorescence Imaging as a Tool to Understand the Impact of Iron Deficiency and Resupply on Photosynthetic Performance of Strawberry Plants. Scientia Horticulturae, 165, 148-155. http://dx.doi.org/10.1016/j.scienta.2013.10.042

[27] Kalaji, H.M., Oukarroum, A., Alexandrov, V., Kouzmanova, M., Brestic, M., Zivcak, M., Samborska, I.A., Cetner, M.D., Allakhverdiev, S.I. and Goltsev, V. (2014) Identification of Nutrient Deficiency in Maize and Tomato Plants by in Vivo Chlorophyll a Fluorescence Measurements. Plant Physiology and Biochemistry, 81, 16-25. http://dx.doi.org/10.1016/j.plaphy.2014.03.029

[28] Ciompi, S., Gentili, E., Guidi, L. and Soldatini, G.F., (1996) The Effect of Nitrogen Deficiency on Leaf Gas Exchange and Chlorophyll Fluorescence Parameters in Sunflower. Plant Science, 118, 177-184. http://dx.doi.org/10.1016/0168-9452(96)04442-1

[29] D’Hooghe, P., Escamez, S., Trouverie, J. and Avice, J. C., (2013) Sulphur Limitation Provokes Physiological and Leaf Proteome Changes in Oilseed Rape That Lead to Perturbation of Sulphur, Carbon and Oxidative Metabolisms. BMC Plant Biology, 13, 23. http://dx.doi.org/10.1186/1471-2229-13-23

[30] Pervez, H., Ashraf, M. and Makhdum, M.I. (2004) Influence of Potassium Nutrition on Gas Exchange Characteristics and Water Relations in Cotton (Gossypium hirsutum L.). Photosynthetica, 42, 251-255. http://dx.doi.org/10.1023/B:PHOT.0000040597.62743.5b

[31] Jiang, D.A., Lu, Q., Xue, J.M. and Xie, X.M. (1992) Regulation of Potassium Nutrition to Photosynthetic Function and Light-Energy Absorption of Rice Leaf. Acta Agriculturae Universitatis Zhejiangensis, 18, 25-29. (In Chinese)

[32] Zhao, D.L., Oosterhuis, D.M. and Bednarz, C.W. (2001) Influences of Potassium Deficiency on Photosynthesis, Chlorophyll Content, and Chloroplast Ultrastructure of Cotton Plants. Photosyntetica, 39, 103-199. http://dx.doi.org/10.1023/A:1012404204910

[33] Xu, Z., Zhou, G. and Shimizu, H. (2010) Plant Responses to Drought and Rewatering. Plant Signaling \& Behavior, 5, 649-654. http://dx.doi.org/10.4161/psb.5.6.11398

[34] Gorbe, E. and Calatayud, A. (2012) Applications of Chlorophyll Fluorescence Imaging Technique in Horticultural Research: A Review. Scientia Horticulturae, 138, 24-35. http://dx.doi.org/10.1016/j.scienta.2012.02.002

[35] Lee, S.H., Sakuraba, Y., Lee, T., Kim, K.W., An, G., Lee, H.Y. and Paek N.C. (2014) Mutation of Oryza Sativa CORONATINE INSENSITIVE 1b (OsCOI1b) Delays Leaf Senescence. Journal of Integrative Plant Biology, 6, 562576. 